Jurnal Bimbingan dan Konseling Ar-Rahman
Volume 7, Nomor 2, Tahun 2021
Tersedia Online: http://ojs.uniska.ac.id/index.php/BKA
e-ISSN 2477-6300

\title{
KETAHANAN KELUARGA DI MASA PANDEMI (STUDI KASUS PADA ISTRI YANG MENJALANI LONG DISTANCE MARRIAGE) DI KABUPATEN KENDAL
}

\author{
Laelatul Anisah, Cahya Milia Tirta Safitri \\ Universitas Selamat Sri \\ laelatulanisah89@gmail.com
}

\begin{abstract}
ABSTRAK
Menjalani long distance marriage bukanlah hal yang mudah, terutama di masa pandemi. Salah satu faktor terbesar yang melatarbelakangi hal tersebut adalah faktor ekonomi. Problematika mengenai long distance marriage ini lebih banyak dirasakan oleh istri, sehingga berdampak pada rentannya ketahanan keluarga. Penelitian ini bertujuan untuk menggali lebih dalam bagaimana ketahanan keluarga di masa pandemi pada istri yang menjalani long distance marriage. Metode yang digunakan adalah metode kualitatif dengan pendekatan fenomenologis. Adapun pengumpulan data mengunakan observasi dan wawancara mendalam. Analisa data dilakukan melalui tiga tahap yaitu reduksi data, penyajian data dan verifikasi data.Partisipan berjumlah tiga orang dengan kriteria istri yang menjalani long distance marriage. Adapun hasil penelitian dari ketiga partisipan menunjukkan bahwa long distance marriage membuat mereka kesulitan dalam berkomunikasi secara efektif, sehingga mengakibatkan perselingkuhan, perubahan perilaku dan pertengkaran yang tidak ada habisnya. Saran dari penelitian ini diharapkan bagi pasangan yang menjalani long distance marriage dapat meningkatkan komunikasi yang intim dan efektif baik melalui media sosial maupun telepon supaya ketahanan yang dibangun sejak awal perkawinan dapat berjalan harmonis.
\end{abstract}

Kata Kunci: Ketahanan Keluarga, Pasangan Long Distance Marriage, Di Masa Pandemi

\begin{abstract}
Living a long distance marriage is not an easy thing, especially during a pandemic. One of the biggest factors behind this is the economic factor. The problem with long distance marriage is mostly felt by the wife, so it has an impact on the vulnerability of the family's resilience. This study aims to dig deeper into how family resilience during the pandemic is for wives who undergo long distance marriage. The method used is a qualitative method with a phenomenological approach. The data collection uses observation and in-depth interviews. Analysis of the data used is descriptive data analysis. Data analysis was carried out in three stages, namely data reduction, data presentation and data verification.There are three participants with the criteria of a wife undergoing long distance marriage. The results of the research from the three participants showed that long distance marriage made it difficult for them to communicate effectively, resulting in infidelity, behavior changes and endless fights. Suggestions from this research are expected for couples who undergo long distance marriage can improve intimate and effective communication both through social media and telephone so that the resilience that was built since the beginning of the marriage can run harmoniously.
\end{abstract}

Keywords: Family Resilience, Long Distance Marriage Couples, During the Pandemic 
Laelatul Anisah, Cahya Milia Tirta Safitri

Jurnal Bimbingan dan Konseling Ar-Rahman

Volume 7, Nomor 2, Tahun 2021

e-ISSN 2477-6300

\section{PENDAHULUAN}

Pandemi covid kini menjadi problematika hampir di seluruh dunia. Begitu banyak hal yang berubah dalam sekejap sejak virus tersebut menyerang. Terutama dalam aspek kesehatan, dimana virus tersebut dapat menular secara cepat dan dapat mengakibatkan kematian. Data per tanggal 14 Juli 2021 yang dilansir dari Our World in Data dan Jhu Csse Covid (2021), menunjukkan saat ini terdapat 2,38 Juta kasus warga Indonesia yang terjangkit Covid. 1,97 jiwa sembuh, dan 62,908 jiwa dinyatakan meninggal. Melihat data tersebut, pemerintah melakukan berbagai upaya preventif untuk meminimalisir penularan dengan menggalakkan program pembatasan secara fisik (phisical distancing) maupun pembatasan kegiatan masyarakat. Adanya pembatasan kegiatan di beberapa wilayah zona merah, berdampak pada sektor ekonomi, pendidikan bahkan sosial budaya. Tidak hanya mengakibatkan kerugian secara materiil, ancaman Covid 19 juga berimbas pada kondisi kesehatan mental. Guna beradaptasi di era disruptif ini, maka diperlukan ketahanan keluarga yang kuat.

Ketahanan keluarga sendiri merupakan alat untuk mengukur pencapaian keluarga dalam melaksanakan peran, fungsi dan tanggung jawabnya dalam mewujudkan kesejahteraan anggota (Musfiroh, dll, 2019). Sementara Puspita, dkk (2020) mendefiniskan ketahan keluarga sebagai kemampuan keluarga untuk menangkal atau melindungi diri dari berbagai permasalahan atau ancaman kehidupan baik yang datang dari dalam keluarga itu sendiri maupun dari luar keluarga seperti lingkungan, komunitas, masyarakat, maupun negara. Adapun dimensi penting dalam ketahanan rumah tangga menurut Cahyaningtyas, dkk (2016) yang dirangkum dalam naskah yang diterbitkan oleh Kementrian Pemberdayaan Perempuan dan Perlindungan Anak dan Badan Pusat Statistik meliputi legalitas dan keutuhan keluarga, ketahanan fisik, ketahanan ekonomi, ketahanan sosial psikologis dan ketahanan sosial budaya.

Keluarga yang memiliki ketahanan kuat akan mampu beradaptasi di segala kondisi termasuk dalam menghadapi pandemi. Terdapat lima indikasi yang menggambarkan tingkat ketahanan keluarga yang antara lain adanya sikap saling melayani sebagai tanda kemuliaan, adanya keakraban suami dan istri menuju kualitas perkawinan yang baik, adanya suami dan istri yang saling memimpin anggota keluarganya dengan penuh kasih sayang dan adanya anakanak yang menaati dan menghormati anggotanya. Namun, seiring kesejahteraan ekonomi yang semakin menurun, banyak keluarga yang sebelumnya mengalami kerentanan akhirnya menyerah pada keadaan, sehingga sistem ketahanan keluarga pun melemah. Seperti yang disampaikan oleh Arlinta (2021) bahwa respon yang tidak tepat dalam menghadapi dampak covid 19 berpotensi memperburuk kondisi kerentanan keluarga yang sudah ada sebelumnya.

Salah satu hal yang dapat menurunkan tingkat ketahanan keluarga akibat pembatasan kegiatan masyarakat adalah banyak keluarga yang terpaksa menjalin hubungan jarak jauh, atau biasa disebut long distance marriage. Long distance marriage merupakan kondisi dimana pasangan suami istri memiliki kendala jarak dan waktu untuk bertemu (Prameswara \& Sakti, 2016). Sementara menurut Kismini,dkk (2018), long distance marriage identik dengan pasangan yang dipisahkan oleh jarak yang tidak memungkinkan kedekatan secara fisik dalam jangka waktu tertentu, sehingga mengakibatkan terbatasnya komunikasi. Kondisi yang demikian tentunya masih kurang optimal untuk dapat memenuhi indikator ketahanan keluarga yang baik, dimana dalam menjalankan long distance marriage, pasangan kurang memiliki sikap saling melayani dan keakraban suami yang terbatas jarak dan waktu. Latar belakang terjadinya long distance marriage kebanyakan karena faktor ekonomi dan tuntutan pekerjaan.

Terlebih bagi seorang istri. Istri yang harus tinggal terpisah dengan suami cenderung akan mengalami beban yang lebih berat, khususnya pada periode awal pernikahan karena masih dalam tahap adaptasi. Adapun sumber konflik yang rentan dialami oleh pasangan long distance marriage adalah keterbatasan dalam berkomunikasi hingga mengakibatkan perbedaan persepsi (Wardhani dkk, 2020). Sejalan dengan pernyataan tersebut, Harsari (2020) dalam penelitiannya mengenai A Perspective Of Husband and Wife Roles In Long Distance Marriage menjelaskan bahwa permasalahan yang sering dialami oleh pasangan long distance marriage adalah kendala dalam berkomunikasi sehingga mengakibatkan perselisihan, kesepian dan kurangnya partisipasi suami dalam pengasuhan anak. Hal tersebut cukup kontras dengan konsep pernikahan harmonis, dimana seluruh anggota keluarga merasa bahagia yang ditandai oleh berkurangnya ketegangan, kekecewaan dan menerima seluruh keadaan dan keberadaan dirinya (eksistensi, aktualisasi diri) 
yang meliputi aspek fisik, mental dan sosial (Gunarsa, 2000).

Keluarga yang tidak memiliki ketahanan dan kurang harmonis akhirnya berujung pada kasus perceraian. Maharrani (2021) mengungkapkan bahwa kasus perceraian meningkat drastis di masa pandemi. Khususnya di Kabupaten Kendal. Terdapat lonjakan kasus dari 4,6\% di tahun 2015 dan kini menjadi 9,1\% di tahun 2021. Hal tersebut umumnya dipicu antara lain karena faktor ekonomi, salah satu pihak meninggalkan pasangan dan juga karena pertikaian yang tak kunjung usai. Adapun sumber dari pertikaian kebanyakan disebabkan karena keterbatasan komunikasi yang sebagian besar disebabkan karena faktor long distance marriage. Meski demikian, tidak semua pasangan long distance marriage mengalami ketidakharmonisan dalam keluarga. Hasil penelitian dengan mentode kuantitatif mengenai marital satisfaction justru menunjukkan bahwa tingkat kepuasan pernikahan pada istri yang menjalani long distance marriage tergolong tinggi, yakni sebanyak $74.65 \%$, sedangkan pada suami, tingkat kepuasaan pernikahan tergolong sedang yaitu sebesar $70.25 \%$ (Putra \& Afdal, 2020). Tingkat kepuasan tersebut didasarkan pada adanya rasa percaya dari pasangan masingmasing dan faktor-faktor lainnya seperti komunikasi, usia pernikahan, pemenuhan kebutuhan seksual, ekonomi dan berdasarkan budaya setempat (Naibaho dkk., 2016)

Berdasarkan latar belakang diatas dan perbedaan hasil penelitian, penulis tertarik untuk melakukan penelitian lebih lanjut mengenai ketahanan keluarga pada pasangan yang menjalani long distance marriage di Kabupaten Kendal. Terutama di masa pandemi, dimana kompleksitas permasalahan mencakup berbagai aspek yang antara lain finansial, psikis maupun perubahan sosial budaya yang disruptif, sehingga mengakibatkan dampak yang beragam pada istri yang menjalani long distance marriage.

\section{METODE}

Penelitian mengenai Ketahanan Keluarga di Masa Pandemi (Studi Fenomenologis Pada Pasangan Long Distance Marriage) menggunakan metode kualitatif dengan pendekatan fenomenologis. Penggunaan pendekatan fenomenologis ditujukan untuk mengkaji lebih dalam mengenai pengalaman individu terhadap peristiwa tertentu. Adapun pengumpulan data menggunakan metode observasi dan wawancara mendalam. Analisa data dilakukan melalui tiga tahap yaitu reduksi data, penyajian data dan verifikasi data. Jumlah partisipan yang terlibat dalam penelitian ini adalah 3 Istri yang menjalani Long Distance Marriage di Kabupaten kendal.

\section{HASIL DAN PEMBAHASAN}

Hasil penelitian menunjukkan gambaran responden berkenaan dengan kondisi keluarga yang LDR di masa pandemi:

Responden pertama; Berdasarkan hasil wawancara awal dengan $\mathrm{H}$, diperoleh gambaran awal (1) sering bertengkar dengan suaminya, (2) jarang komunikasi, (3) tidak diperhatikan lagi, (4) sering salah paham. Selain melakukan wawancara dengan responden peneliti juga melakukan wawancara dengan tetangga responden. Berdasarkan hasil wawancara diketahui bahwa suami responden sudah lama tidak pulang bahkan sudah 1 tahun yang biasanya pulang 3 bulan sekali selama pandemi tidak pulang sama sekali.

Padahal mereka sudah terbiasa LDR sejak pacaran. Saat pacaran dahulu tidak pernah sekalipun bertengkar, saling mengerti akan tetapi setelah keduanya menikah menjadi sering berbeda pendapat, berbeda cara pandang dan berfikir. Responden merasa sedih dengan sikap suaminya yang tidak seperti dulu. Setiap ngobrol via chat selalu membalas dengan sikap dingin padahal responden sebelumnya orang yang sangat hangat. Responden merasa curiga apa yang selama ini terjadi pada suaminya. Seperti bukan suami yang dia kenal selama ini.

Responden Kedua; Berdasarkan hasil wawancara awal dengan $\mathrm{H}$, diperoleh gambaran awal (1) sering pergi dengan teman-temannya, (2) asyik dengan gadgetnya, (3) tidak pernah perhatian terhadap keluarganya. Selain melakukan wawancara dengan responden peneliti juga melakukan wawancara dengan keluarga responden. Berdasarkan hasil wawancara diketahui bahwa suaminya sering pergi dengan teman-temannya dan jarang berkumpul dengan keluarga.

Sebelumnya, responden ini tidak ada masalah di dalam rumah tangganya, seperti ekonomi atau apa bahkan pasangan ini juga sudah dikaruniai seorang anak. Responden semakin yakin bahwa faktor utama yang menjadikannya berubah yaitu faktor lingkungan, karena sejak bekerja di Kota Semarang yang termasuk kota besar yang mana pengalaman serta lingkungan yang membuat suami berubah.

Satu tahun belakangan ini suaminya kepergok dugem dengan wanita lain di sebuah 
karaoke di Kota Semarang ditempat kerjanya tersebut di lihat dari gadget suaminya akhirnya perselingkuhan tersebut terkuak karena responden menemukan foto yang tidak senonoh dan chat mesra dengan perempuan lain.

Klien ketiga; Berdasarkan hasil wawancara awal dengan $\mathrm{H}$, diperoleh gambaran awal (1) sering bertengkar baik secara langsung maupun tidak langsung, (2) sering cemburu, (3) tidak percaya. Selain melakukan wawancara dengan responden peneliti juga melakukan wawancara dengan orangtua dari responden. Berdasarkan hasil wawancara diketahui bahwa suaminya sering bertengkar baik kalau ketemu maupun tidak ketemu karena curiga dengan pasangan kalau tidak setia.

Hasil penelitian diatas menunjukkan bahwa tiga istri yang menjalani long distance marriage memiliki ketidakpuasan terhadap perkawinannya, dimana hal tersebut tidak sesuai dengan konsep pernikahan yang menurut Papalia, Olds dan Feldman (dalam Winta \& Nugraheni, 2019), idealnya dalam pernikahan mampu menciptakan kedekatan, pertemanan, pemenuhan kebutuhan seksual, kebersamaan dan perkembangan emosional antar pasangan. Salah satu faktor yang melatarbelakangi ketidakpuasan suami istri yang menjalani hubungan jarak jauh adalah minimnya komunikasi.

Pasangan harus bisa mengerti kondisi dan keadaan. komukasi sangatlah penting hubungan long distance marriage masalah tersebut diperparah dengan jarangnya waktu bertemu dengan pasangan dan juga rasa rindu pada pasangan yang tidak tersalurkan. Komunikasi secara tatap muka dinilai lebih efektif ketika menyelesaikan suatu masalah karena pesan bisa langsung tersampaikan dengan baik. Perhatian yang diberi ketika menjalankan hubungan long distance marriage online, seperti menghabiskan waktu bersama melalui chat atau telepon, memengaruhi kepuasan hubungan secara positif. Tetapi, perlu diingat bahwa metode komunikasi mempengaruhi setiap orang secara berbeda-beda tergantung metode apa yang lebih cocok. Mungkin sebuah pasangan lebih nyaman berkomunikasi melalui telepon, ada yang lebih suka berkomunikasi lewat chat, bahkan ada juga yang memilih untuk berkomunikasi melalui email. Metode komunikasi yang sesuai bagi sebuah pasangan harus dicari tahu untuk mengetahui cara terbaik bagi mereka untuk berkomunikasi. Menemukan bahwa kepuasan hubungan dapat memengaruhi kualitas hubungan yang dilakukan secara online. Hubungan long distance marriage diperlukan saling percaya, mengerti dan memahami keadaan pandemi seperti ini

Bahwa setiap perkawinan bertujuan untuk membangun keluarga sakinah, keluarga yang bahagia. Dan perkawinan hendaknya di jaga dengan baik seumur hidup. Karena perkawinan adalah ikatan lahir batin antara seorang pria dan wanitayang saling mencintai sebagai suami istri. Problematika perselingkuhan suami terhadap istri dapat menjadi sumber stres yang luar biasa. Kegagalan pasangan untuk saling menyesuaikan diri dan memecahkan masalah-masalah secara efektif dapat memicu konflik yang berkepanjangan. Dari keseluruhan problematika perselingkuhan, maka problematika yang paling utama dari perselingkuhan adalah perceraian, karena perselingkuhan merupakan salah satu masalah putusnya perkawinan. Perselingkuhan adalah penyebab utama perceraian

Keluarga yang harmonis yang didambakan setiap pasangan suami-istri sangat enak untuk didengarkan, tetapi sulit diwujudkan. Maka perlu diusahakan dengan sungguh-sungguh tanpa mengenal putus asa.Membina keluarga harmonis adalah usaha suami istri. Kalau ada hambatan maka harus diatasi bersama. Kalau usaha hanya dijalankan hanya dari sebelah pihak, maka tujuan tidak akan tercapai dan segala masalah tidak akan terpecahkan. Hambatanhambatan akan selalu ditemui, namun dengan usaha yang benar tanpa mengenal lelah dari kedua belahfihak akan membuahkan hasil. Kalau hambatan yang ditemui tidak bisa dipecahkan berdua maka diperlukan bantuan orang lain. Suami istri tidak perlu malu-malu untuk mengungkapkan permasalahannya kepada orang yang dianggap mampu untuk membantu menyelesaikan masalah keluarga.

\section{PENUTUP}

Berdasarkan hasil penelitian mengenai ketahanan keluarga (studi fenomenologis pada istri yang menjalankan Long Distance Marriage) dapat disimpulkan bahwa Long distance marriage membuat pasangan kesulitan dalam berkomunikasi secara efektif, sehingga mengakibatkan perselingkuhan, perubahan perilaku dan pertengkaran yang tidak ada habisnya pada masing-masing pasangan. Saran dari penelitian ini diharapkan bagi pasangan yang menjalani Long distance marriage dapat meningkatkan komunikasi yang intim dan efektif baik melalui media sosial maupun telepon supaya ketahanan yang dibangun sejak awal perkawinan dapat berjalan harmonis. Dan untuk peneliti selanjutnya untuk dasar dalam 
melaksanakan penelitian sehingga dapat menemukan hasil penelitian yang akan diteliti.

\section{REFERENSI}

Aditama. Daradjat, Z. (1994). Problema Remaja Indonesia. Jakarta : PT. BulanBintang.

Agustian, H. (2013). Gambaran Kehidupan Pasangan yang Menikah di Usia Muda di Kabupaten Dharmasraya. Spektrum PLS, 1(1), 205-217.

Algoe, S. B., \& Kurtz, L. E. (2015). Putting laughter in context: Shared laughter as behavioral indicator of relationship well-being. Personal Relationships, 22, 573-590.doi:10.1111/pere.12095.

Bazzini, D. G., Stack, E. R., Martincin, P. D., \& Davis, C. P. (2007). The effect of reminiscing about laughter on relationship satisfaction. Motivation and Emotion, 31, 25-34. doi:10.1007/s11031-006-9045-6.

Corey G. (2005). Teori dan Praktek Konseling dan Psikoterapi. Bandung: Refika.

Creasy, B., Gentzler, A., Morey, J., Oberhauser, A. and Westerman, D., (2013). Young adults' use of communication technology within their romantic relationships and associations with attachment style. Computers in Human Behavior, 29(4), pp.1771- 1778.

Creswell, John W. (2009). Research Design Qualitative, Quantitative, and Mixed Methods Approaches. California : Sage Publications.

Dargie, E., Blair, K. L., Goldfinger, C., \& Pukall, C. F. (2015). Go long! Predictors of positive relationship outcomes in long-distance dating relationships. Journal of sex \& marital therapy, 41(2), 181-202.

Devito, Joseph A. (1997). Komunikasi Antar Manusia. Jakarta : Professional Books

Drapeau, A., Marchand, A., \& BeaulieuPrevost, D. (2012). Epidemiology of Psychological Distress. Mental Illnesses - Understanding, Prediction and Control.doi: 10.5772/30872.

Elisa. (2017). Seputar Paradigma Interpretif. www.ugm.ac.id. Diakses pada 26 April2021.

Gunarsa, SD. (2000). Psikologi untuk Keluarga. Jakarta: Gunung Mulia.

Hadisubrata. (2003). Keluarga dalam Dunia
Modern, Tantangan dan Pembinaannya. Jakarta: BPK Gunung Mulia.

Hall, J. A. (2017). Humor in romantic relationships: A meta-analysis. Personal Relationship, 24(2), 306-322. doi: 10.1111/pere.12183.

Hidayat, Dasrun. (2012). Komunikasi Antar Pribadi dan Medianya. Yogyakarta : Grahallmu.

Kurniati, Girly. (2015). Studi Penetrasi Sosial Pasagan Yang Terpisahkan Jarak Geografis. Jurnal Komunikasi Indonesia.

Latipun. (2001). Psikologi Konseling. Malang: UMM Press.

Littlejohn, Stephen W dan Karen A. Foss. (2016). Ensiklopedia Teori Komunikasi. Jakarta: Salemba Humanika.

Nick. (2002). Keluarga Kokoh dan Bahagia. Batam: Interaksara.

Pimpinan Pusat Aisyiyah. (tanpa tahun). Membina Keluarga Sakinah, Yogyakarta:Bengkel Keluarga.

Pistole, M. C., Roberts, A., \& Chapman, M. L. (2010). Attachment, relationship maintenance, and stress in long distance and geographically close romantic relationships. Journal of Social and Personal Relationships, 27(4), 535-552. https://doi.org/10.1177/026540751036 3427.

Pribadi, S. (1991). Filsafah Kehidupan Berkeluarga. Bandung: Yayasan Sekolah Bijaksana.

Pujosuwarno, S. (1994). Bimbingan Konseling Keluarga. Yogyakarta: Menara Mas Offset.

Surya, M. (2003). Teori-Teori Konseling. Bandung: CV Pustaka Bani.

Walgito, B. (2001). Bimbingan dan Konseling Perkawinan. Yogyakarta: Yayasan Penerbit Fakultas Psikologi Universitas Gajah Mada.

Waterman, E. A., Wesche, R., Leavitt, C. E., Jones, D. E., \& Lefkowitz, E. S. (2017). Long- Distance Dating Relationships, Relationship Dissolution, and College Adjustment. Emerging Adulthood, 5(4), 268-279. https://doi.org/10.1177/216769681770 $\underline{411}$

Willis, S. (2008). Konseling Keluarga (Family Counseling). Bandung: Alfabeta. 